\title{
Verbal and Nonverbal Teacher Immediacy and Foreign Language Anxiety in an EFL University Course
}

Elisabet Pladevall Ballester

Universitat Autònoma de Barcelona

Received: 16 May 2013 / Accepted: 29 October 2013

ISSN: $1697-7467$

\begin{abstract}
How teachers communicate to students is one of the crucial elements that enhance affective and cognitive learning in a foreign language learning class. This study explores the perceptions of three groups of university students on verbal and nonverbal teacher immediacy and how this might be related to a decrease in foreign language anxiety. Significant differences between the groups were found in terms of immediacy and anxiety but no direct correlations were established. However, a qualitative analysis of the students' perceptions indicated that teacher immediacy is indeed a key factor to motivate students, ease their pressure and favour their willingness to learn and participate in class.

Keywords: verbal and nonverbal immediacy, foreign language anxiety, affective learning, cognitive learning.
\end{abstract}

Proximidad verbal y no-verbal del profesor y ansiedad en el aprendizaje de lenguas extranjeras en un curso universitario de inglés como lengua extranjera

RESUMEN: La manera como los profesores se comunican con sus alumnos es un elemento crucial para incentivar el aprendizaje afectivo y cognitivo en una clase de lengua extranjera. Este estudio analiza las percepciones de tres grupos de estudiantes universitarios sobre la proximidad verbal y no-verbal de sus profesores y como estas percepciones se relacionan con un posible descenso de la ansiedad en el aprendizaje de lenguas extranjeras. Se encontraron diferencias significativas entre los grupos por lo que respecta a proximidad y ansiedad pero no se encontraron correlaciones directas. No obstante, un análisis cualitativo de las percepciones de los alumnos indicó que la proximidad del profesor es un factor determinante para motivar a los alumnos, relajar la presión y favorecer su disposición a aprender y participar en clase.

Palabras clave: proximidad verbal y no-verbal, ansiedad en el aprendizaje de lenguas extranjeras, aprendizaje afectivo, aprendizaje cognitivo.

\section{INTRODUCTION}

The way teachers communicate to students is one of the many factors that help determine effective teaching and how this is perceived by students might affect their affective and cognitive learning and their feelings throughout the learning process. Verbal and nonverbal immediate behaviours on the part of the teacher enhance positive and effective instructional interaction, which has direct effects on the students' attitudes towards the teacher and the 
course and the students' willingness to learn (Andersen, 1979; Gorham, 1988; Plax, Kearney, McCroskey, \& Richmond, 1986; Richmond et al., 1987; Christophel, 1990; McCroskey and Richmond, 1992; Rodriguez, Plax, \& Kearney; 1996; Chesebro and McCroskey, 1998; Witt \& Wheeless, 2001; Richmond, 2002; McCroskey, Richmond and McCroskey, 2005; Pogue and AhYun, 2006). In a context of English as a Foreign Language (EFL) first year university core course in a degree of English Studies, this study seeks to explore how the teachers' approachability or lack of thereof might be related to the students' levels of Foreign Language (FL) anxiety and perceptions of affective and cognitive learning. The EFL course under study creates high levels of FL anxiety among first year students, as the groups are quite large for an EFL course and the students' level of English is rather heterogeneous and generally lower than required. Three groups of students with three lecturers differing in degree of immediacy, as previously determined by external observers, participated in the study. The students were asked to rate their teachers' verbal and nonverbal immediacy and their own feelings of foreign language anxiety and they were also asked to provide their perceptions on their affective and cognitive learning as related to their lecturer's immediacy. The study aims to analyse the students' perceptions of teachers' immediacy, determine if they correspond to the ones provided by the observers and explore how they relate to the students' perceptions of FL anxiety and affective and cognitive learning. More specifically, the research questions of the study are: (1) Are there significant differences in the students' perceptions of verbal and nonverbal immediacy within each of the groups? (2) Are there significant differences in the students' perceptions of verbal and nonverbal immediacy and FL anxiety between the three groups? (3) Is there any relationship between the students' perceptions of FL anxiety and verbal and nonverbal teacher immediacy behaviours in each of the groups? (4) How have the students' perceptions of teacher immediacy affected their affective and cognitive learning?

A brief review of studies of immediacy and instruction will be first provided, followed by a section on FL anxiety and its relationship with teachers' immediacy. The methodology of the study will be then presented, the results described and discussed and some final conclusions will be drawn.

\section{VERBAL AND ONVERBAL IMMEDIACY}

Richmond (2002) defines immediacy as "the degree of perceived physical or psychological closeness between people" (p. 68). Immediacy is a communication behaviour and involves verbal and nonverbal elements. Originally developed by Mehrabian (1969), a substantial amount of research has related it to effective teaching and to an increase in students' motivation (See McCroskey et al., 2005). The function of a teacher should be to create a class atmosphere that enhances students' affect for the subject matter being taught and the teacher him/herself and increases students' motivation and willingness to learn. In turn, this should ultimately improve students' cognitive learning, which is defined as what can be recalled, understood and synthesised from newly acquired content (Witt, Wheeless and Allen, 2004).

Verbal teacher immediacy refers to verbal messages that show empathy, openness, kindness, reward, praise, feelings of inclusiveness, humour, personal knowledge and willingness to engage students in communication, among others. Inevitably linked to nonverbal immediacy behaviours, verbal immediacy has been associated with increased cognitive and affective learning and with increased motivation (Gorham, 1988; Cristophel, 1990; Plax, 
Kearny, McCroskey and Richmond, 1986; Richmond, McCroskey, Kearny and Plax, 1987; Rodríguez, Plax and Kearny, 1996). A high correlation exists between verbal and nonverbal immediacy (Edwards and Edwards, 2001) but nonverbal immediacy may exist independently of verbal messages and this is why it is often given more importance in classroom research. Nonverbal teacher immediacy refers to nonverbal behaviours that induce physical and emotional closeness which in turn increase students' affect towards the teacher, the course and the content (Richmond and McCroskey, 2000). By communicating through immediate behaviours, teachers establish a positive relationship with students and create a positive environment in class which translates as students being more interested and motivated and learning more effectively. These nonverbal cues include eye contact, body position and movement, appropriate touching and facial and vocal expression (Richmond, Gorham and McCroskey, 1987) and similarly to verbal immediacy, perceptions of nonverbal immediacy have been shown to increase affective, cognitive and behavioural learning, motivation and perceptions of clarity and credibility (Richmond, Gorham and McCroskey, 1987; Pogue and AhYun, 2006; Hsu, 2010, among others). Other studies have associated increased teacher immediacy and subsequent relaxed classroom atmosphere with lower levels of different types of anxiety in the classroom, such as communication and receiver apprehension (Chesebro and McCroskey, 1998; Richmond and McCroskey, 1998; Messman and Jones-Corely, 2001). Immediate behaviours will primarily increase students' affect for the teacher and the course. As to why teacher immediacy should lead to students' learning, two explanations were put forward, namely arousal-attention (Kelley and Gorham, 1988) and motivation (Cristophel, 1990; Richmond, 1990). Immediate behaviours attract the attention of students, who are likely to pay more attention and remember more content and at the same time students' perceptions of immediacy may motivate them more to make an effort to learn.

Richmond (2002) summarised the outcomes of immediate behaviours indicating that teacher immediacy results in higher levels of affect for the teacher and the content of the course, higher levels of cognitive learning, student motivation and teacher-student interaction, lower levels of resistance to the teacher, classroom anxiety and status differences between teachers and students, higher perceptions of teacher's clarity, credibility and competence and higher evaluations from students and supervisors. All these indicators clearly favour any educational experience but even more the teaching of a foreign language in which affect and positive emotions play a crucial role (MacIntyre and Gregersen, 2012a, 2012b; Hsu, 2010; Myers and Bryant, 2002). The teaching and learning of a foreign language necessarily requires a relaxed environment, where students feel comfortable enough to participate and interact and where they are encouraged to learn more. This is especially important in the context under study, where students feel pressured to acquire a certain level of English in order to pass the course in large groups and in a situation of minimal exposure.

\section{Foreign language andiety}

Horwitz, Horwitz and Cope (1986) conceptualised Foreign Language Anxiety as a specific type of anxiety which causes students' negative emotional reactions to foreign language learning situations and distinguished it from other types of anxiety also present in a classroom context, such as test anxiety or fear of negative evaluation anxiety. The authors claim that this anxiety arises from poor foreign language communicative skills: 
...second language communication entails risk-taking and is necessarily problematic. Because complex and nonspontaneous mental operations are required in order to communicate at all, any performance in the L2 is likely to challenge an individual's self-concept as a competent communicator and lead to reticence, self-consciousness, fear, or even panic (p. 128).

Anxious learners find it extremely difficult to participate in speaking or any other activities in the classroom, to remember previously learned material or to pay attention when listening to foreign language input (Horwitz et al., 1986). They experience a high degree of frustration and tend not to respond effectively to their own mistakes (Gregersen, 2003). All this tends to result in lower course grades (Gardner, 1985) and more specifically less motivation and lower levels of language achievement in all four skills (Deawele, 2007; Gardner and MacIntyre, 1993; MacIntyre and Gardner, 1991; Saito et al. 1999; Sellers, 2000, among others). Although research has found a relationship between poor foreign language learning and high levels of anxiety it remains to be seen if language anxiety causes language problems or if it is poor language achievement that entails anxiety (see Horwitz, 2001). It is clear that FL anxiety should be dealt with in the EFL classroom and that a variety of strategies should be used in order to provide positive reinforcement to students. Apart from teamwork, formative assessment or meaning-focused instruction, teacher immediacy may indeed play a crucial role in decreasing levels of FL anxiety. Gregersen (2005) studied the nonverbal behaviour of anxious and non-anxious students in an EFL oral exam and found significant differences, which might help teachers identify those learners that need special attention in specific learning situations. The author also suggests that by being more immediate, teachers might create more positive feelings and increase student affect. Thus, in order to ease the levels of FL anxiety, teachers should not only interpret students' nonverbal behaviour but also provide nonverbal immediate behaviour themselves.

An important element to consider when exploring FL anxiety and immediacy is the students' cultural background, as their perceptions of what is immediate or how this might affect their feelings in class might depend on their expectations of immediacy. For highly immediate cultures, a lecturer from a non-immediate, more distant culture might be perceived as cold, distant or even arrogant, whereas students with a non-immediate cultural background might feel uncomfortable in highly immediate situations, which might even create FL anxiety. Gregersen (2006) studied the relationship between students' ratings of instructor immediacy and FL anxiety in Chilean and Russian English classrooms representing clearly different cultures in terms of immediacy. Results indicated that Chilean learners perceived their instructors significantly more immediate than their Russian counterparts, as expected, but they reported feeling significantly more anxious than the Russian students, which the author attributes to the concept of image-consciousness and the importance of the opinion of others that are present in the Chilean culture. No correlation was found between immediacy and anxiety in the case of the Chilean students and a slightly negative correlation was found between FL anxiety and only one particular nonverbal immediacy behaviour in the case of the Russian students, so FL anxiety in such contexts was shown not to be influenced by instructor immediacy and was said to be influenced by other variables. 


\section{Methodology}

\subsection{Context of the Study and Participants}

Three groups of first year students in a degree of English Studies were selected for the study. They were all registered in an EFL Advanced course which is compulsory in their first year and which assumes an entrance level of B2 of the Common European Framework of Reference for Languages and leads them to $\mathrm{C} 1$ at the end of the academic year. Many of the students do not have the required level of English at the start of the course, which together with the fact that around 40 students per group attend class regularly, makes the teaching and learning of English problematic. Although continuous and formative assessment is encouraged, students are required to have a $\mathrm{C} 1$ level of English to pass the course (i.e. to pass a final $\mathrm{C} 1$ exam) and they are required to pass both the written and oral parts of the exam. Students tend to feel considerably anxious all throughout the course and although they have all been learning English as a foreign language for a number of years when they start, their level of English is generally lower than what would be desirable to comfortably pass the course.

Group A was made up of 36 ( 28 female and 8 male) students with a mean age of 20.22 and a mean length of English language learning of 11.88 years. Group B was composed of 29 (25 female and 4 male) students with a mean age of 19.26 and a mean length of English language learning of 11.36 years. Group C was made up of 43 (35 female and 8 male) students with a mean age of 19.71 and a mean length of English language learning of 11.08 years. All of them were Catalan/Spanish bilinguals. Some of them showed no preference for one language over the other and some others showed preference for one of the two languages. The groups were larger but participation in the study was voluntary and not everyone attended class on the day the data were collected.

The three groups tested had three different lecturers with varying amounts of experience in the EFL course at hand. The teacher in Group A was very young, had recently obtained a Master's degree and had just started her PhD. It was the first time she taught at university and hence the first time she taught the course. The teacher in Group B did not hold a PhD but was an experienced teacher at university. She was new in the Department and hence also new in the course. She had taught EFL courses at university before but not this Advanced EFL course. The teacher in Group $\mathrm{C}$ held a $\mathrm{PhD}$ and was much younger than the teacher in Group B but had been teaching this course for eight years. The three different teacher profiles represented three different degrees of immediacy behaviours, inevitably linked to their different experiences within the context studied. Previous to the study and in order to confirm the existence of different degrees of immediacy, three external observers were asked to rate the three teachers in terms of immediacy using the same immediacy questionnaire as the students. The three observers, who were Master's students who did not know the lecturers in the study, attended class with the three lecturers and rated their verbal and nonverbal immediacy behaviours.

\subsubsection{Instruments and Data Collection}

The three groups of students were asked to complete two questionnaires on different days to obtain their perceptions of teacher immediacy and FL anxiety, namely the Verbal 
and Nonverbal Immediacy Items questionnaire (Gorham, 1988) and the Foreign Language Classroom Anxiety Scale (FLCAS) (Horwitz, Horwitz and Cope, 1991).

The Verbal and Nonverbal Immediacy questionnaire (Gorham, 1988) was developed in an attempt to incorporate verbal immediacy items to the already validated and reliable Nonverbal Immediacy Measure developed by Richmond, Gorham and McCroskey (1987). It is a 34-item instrument that measures the students' perceptions of their instructor's verbal and nonverbal immediate behaviours on a 5 point Likert scale $(1=$ never, $2=$ rarely, $3=$ occasionally, $4=$ often, $5=$ very often). It consists of 20 verbal items, such as "Addresses students by name" and 14 nonverbal items, such as "Moves around the classroom while teaching". One of the original 14 nonverbal items was eliminated, namely "Touches students in the class" so as not to create possible misunderstandings during the completion of the questionnaire. In any case and as Gregersen (2006) points out, touching is a virtually non-existent element in university lectures or seminars. Other verbal and nonverbal items were slightly modified and adapted to our context, for instance the regular use of e-mail was mentioned instead of the use of the telephone. The final version of the questionnaire consisted of 33 items ( 20 verbal items and 13 nonverbal items), some of which exemplified non-immediate behaviours and some others represented immediate behaviours (see Appendix A). Reversed scores were given to non-immediate items so that high scores always represented high levels of immediacy.

The Foreign Language Classroom Anxiety Scale (FLCAS) (Horwitz et al. 1991) is a 33-item instrument that measures foreign language learning anxiety and mainly focuses on foreign language speaking on a 5-point Likert scale $(1=$ Strongly Disagree, $2=$ Disagree, $3=$ Neither Agree nor Disagree, 4=Agree, 5=Strongly Agree) (see Appendix B). As in the case of the immediacy questionnaire, some items are worded negatively so reverse scores were given in those cases so as to ensure that high scores always correspond to high levels of anxiety. The FLCAS scale is reliable and valid (with an alpha coefficient of .93) according to Horwitz (1991).

Students were also asked to answer three open-ended questions in their L1 in order to examine their perceptions on immediacy and its relationship with cognitive and affective learning in a more qualitative manner. The three questions students were asked to answer were: (1) How much influence has your language instructor's approachability (or lack thereof) had on your language learning this year? (2) How could your language teacher's instruction be modified to better meet your emotional and/or psychological needs? and (3) Do you think your language skills have improved over the year? In what ways? Students' responses were transcribed and categorised for each of the groups in order to conduct content analysis of the data and complete the picture of their feelings of perceived lecturer immediacy and student anxiety.

\section{Results}

As outlined in the Methodology section, three external observers rated the three lecturers' verbal and nonverbal immediacy previous to the study to confirm that they differed in their degree of approachability. A one-way between subjects ANOVA was conducted to compare the mean scores of perceived immediacy by external observers of the three lecturers 
involved in the study. There was a significant effect of the type of lecturer on the observers' perception of verbal and nonverbal immediacy at the $\mathrm{p}<.05$ level for the three groups $[\mathrm{F}$ $(2,6)=163.979, \mathrm{p}=0.000][\mathrm{F}(2,6)=90.048, \mathrm{p}=0.000]$. Post-hoc comparisons using the Bonferroni test indicated that the mean score of verbal immediacy for Teacher $A(M=2.31$, $\mathrm{SD}=0.11)$ was significantly lower than the mean score for Teacher $\mathrm{B}(\mathrm{M}=3.28, \mathrm{SD}=0.05)$ and Teacher $C(M=4.00, S D=0.15)$ and that the mean score for Teacher $B$ significantly differed from that of Teacher C. As for nonverbal immediacy, the mean score for Teacher A $(\mathrm{M}=3.41, \mathrm{SD}=0.16)$ was also significantly lower than the mean score for Teacher $\mathrm{B}(\mathrm{M}=$ $4.28, \mathrm{SD}=0.11)$ and Teacher $\mathrm{C}(\mathrm{M}=4.66, \mathrm{SD}=0.04)$ and that the mean score for Teacher $\mathrm{B}$ also differed significantly from that of Teacher $\mathrm{C}$. These results showed that the three lecturers indeed differed in their degree of verbal and nonverbal immediacy and allowed us to analyse the students' perceptions of their immediacy to see if they corresponded to the observers' ratings.

The results of the students' perception of the teachers' verbal and nonverbal immediacy behaviours are displayed in Table 1. Another one-way between subjects ANOVA was conducted to compare the mean scores of the students' perceived immediacy of their lecturers and a significant effect was found for both verbal and nonverbal immediacy at the $\mathrm{p}<.05$ level for the three groups $[\mathrm{F}(2,105)=249.940, \mathrm{p}=0.000][\mathrm{F}(2,105)=133.803, \mathrm{p}=0.000]$. Post-hoc Bonferroni comparisons between groups are also shown in Table 1:

Table 1: Descriptive statistics and group comparisons of verbal and nonverbal immediacy perceptions.

\begin{tabular}{|c|c|c|c|c|c|c|}
\hline & Group & $\mathrm{N}$ & Mean & $\mathrm{SD}$ & $\begin{array}{c}\text { Group } \\
\text { comparisons }\end{array}$ & Sig. \\
\hline \multirow{4}{*}{ Verbal Immediacy } & $\mathrm{A}$ & 36 & 2.78 & 0.32 & A-B & .000 \\
\cline { 2 - 7 } & $\mathrm{B}$ & 29 & 3.30 & 0.30 & A-C & .000 \\
\cline { 2 - 7 } & $\mathrm{C}$ & 43 & 4.13 & 0.19 & $\mathrm{~B}-\mathrm{C}$ & .000 \\
\hline \multirow{3}{*}{ Nonverbal Immediacy } & $\mathrm{A}$ & 36 & 3.31 & 0.39 & A-B & .000 \\
\cline { 2 - 7 } & $\mathrm{B}$ & 29 & 4.13 & 0.28 & A-C & .000 \\
\cline { 2 - 7 } & $\mathrm{C}$ & 43 & 4.40 & 0.20 & B-C & .001 \\
\hline
\end{tabular}

As in the case of the observers, the students' perceptions of their lecturers' approachability showed significantly different ratings between the three groups.

In order to analyse possible differences between the students' perceptions of verbal and nonverbal lecturer immediacy within each group, a paired samples t-test was conducted for each of the groups. Perceptions of nonverbal immediacy were significantly higher than verbal immediacy in all groups: $\mathrm{t}(35)=-6.195, \mathrm{p}=.000$ for Group $\mathrm{A}, \mathrm{t}(28)=-14.920, \mathrm{p}=.000$ for Group B and $\mathrm{t}(42)=-7.391, \mathrm{p}=.000$ for Group C.

The mean scores of the students' reported anxiety in each group were also compared and a significant effect was found at the $\mathrm{p}<.05$ level for the three groups $[\mathrm{F}(2,105)=22.810$, 
$\mathrm{p}=0.000]$. Post-hoc Bonferroni comparisons between groups showed that students' means in Group A significantly differ from those of Groups B and C but that these two groups do not differ significantly. Table 2 displays the results on anxiety:

Table 2: Descriptive statistics and group comparisons of anxiety perceptions.

\begin{tabular}{|c|c|c|c|c|c|c|}
\hline & Group & $\mathrm{N}$ & Mean & SD & $\begin{array}{c}\text { Group } \\
\text { comparisons }\end{array}$ & Sig. \\
\hline \multirow{3}{*}{ Anxiety } & A & 36 & 3.56 & 0.36 & A-B & .000 \\
\cline { 2 - 7 } & $\mathrm{B}$ & 29 & 2.81 & 0.54 & A-C & .000 \\
\cline { 2 - 7 } & $\mathrm{C}$ & 43 & 2.89 & 0.58 & B-C & 1.000 \\
\hline
\end{tabular}

So as to explore whether there existed a relationship between perceived anxiety and perceived lecturer verbal or nonverbal immediacy, a Person correlation coefficient was computed, but unfortunately no relationships could be established between students' perceived anxiety and lecturer immediacy. No correlation coefficient was higher than 0.3 and no significance could be observed in any of the correlations. It is true that perceived anxiety differs significantly between Group A and Groups B and C and that immediacy values are significantly lower in Group A than in the other two groups but the two variables cannot be statistically related and hence anxiety in these EFL contexts might be derived from other factors.

In order to explore our last research question on how students perceive immediacy in relation to their affective and cognitive learning and to further explain quantitative results, three open questions were answered by the students. The first question was How much influence has your language instructor's approachability (or lack thereof) had on your language learning this year? Students in Group A generally agree on the fact that the teacher was quite distant during the first semester and that her way of teaching and correcting students was a bit harsh, which did not help students' motivation. At the time the study was conducted, students reported having seen small changes in the teachers' approachability and report feeling they started to learn more and improve their language skills. They all think that the lecturer's approachability is linked to students' learning somehow: 'In a course like this, I think it's essential that the teacher worries about knowing what the strengths and weaknesses of students are and to do this she should be approachable. This would make us feel more comfortable and we would make the most of it'. Another student points out that 'a teacher's attitude and approachability towards students are fundamental so that students can be more self-confident when learning. At the beginning of the course, the teacher was distant but now she's more immediate and tries to help us more'. Some students reported feeling as if they were being judged and that they perceived she was so demanding that they were lost and ended up not doing anything. Very interestingly, a student states that the teacher shows lack of self-confidence and lack of knowledge of the course, materials and necessary tools to transmit knowledge: 'I feel she can't solve my doubts'. Students in Group B generally think that teacher immediacy affects their learning as well. They emphasise that the teacher had improved her attitude during the course because 'she didn't really connect with her 
students at the beginning' and that a relaxed atmosphere makes students not so nervous or insecure when expressing themselves. Some students point out that being approachable means treating all students in the same way and that if the teacher is approachable students gain self-confidence. A student states that there are too many students in the class for teacher approachability to be a factor in their language learning and some others think that the teacher manages to be approachable in her office but not in class. Students in Group $\mathrm{C}$ emphasise the fact that by being immediate the teacher has managed to personalise the students' learning. They state that because the teacher knows them well they do not feel pressure to achieve certain standards and that learning is encouraged no matter what the result is. Motivation and positive reinforcement are highlighted as two main characteristics of the lecturer in Group C: 'I think the fact she's not distant at all has really helped me learn English. Thanks to this approachability it is easier to cope with mistakes instead of getting discouraged. As the teacher knows us all, we don't feel pressured and you get more interested in the course and it's easier to pay attention and not feel lost'. Some students also highlight that it is essential to perceive that the teacher makes an effort in order for them to get involved and make an effort: 'Her constant dedication makes students work more and be more constant and hard-working as well'. In sum, students from the three groups generally think that teacher immediacy helps the students' learning process both in cognitive and affective terms.

The second question was How could your language teacher's instruction be modified to better meet your emotional and/or psychological needs? Students in Group A point put the need to motivate students in class. They complain that the teacher emphasises what they do wrong in an impulsive and aggressive manner and that this makes them feel anxious in class. Some students think the teacher should be more patient and slow down the rhythm of the class and claim that if the teacher is demanding but not approachable, this creates insecurity among them: 'She should soften her constant strict demand because we feel inhibited and not willing to participate in class as we are afraid of committing mistakes'. Lack of selfconfidence appears to be a crucial factor in the teacher's attitude, which is described by a group of students as 'being on the defensive', 'focusing more on what's incorrect than on what is right' and 'always asking the same students'. Students suggest working in groups because sometimes the way the teacher addresses them is intimidating: 'What she should do is encourage us and not shout at us and get angry at us because of our results. It's better to be encouraged. If they yell at me I get collapsed and I can't follow or improve, I'm not capable of learning that way'. In Group B, students report more immediate behaviours but generally ask for more dynamic and interactive lessons which would encourage them to participate more. Students think that the teacher should not treat the group as a whole and they would like more personalised and individualised comments on their performance. Similarly to Group A, some students in this group also feel the need to address both high and low-level students in class: 'The teacher should not only look at the best students but try to get low-level students to improve as well'. A student summarises the general feeling of anxiety that the course creates: 'I feel this language course puts too much pressure on students, I feel as if everyone will look down on me if I make a mistake'. Group C's students highlight the importance of having a teacher who is both agreeable and demanding in class as one of the key elements to get the students feel confident and willing to learn: 'The teacher interacted with us and made us feel comfortable and at the same time she was 
strict and demanding and liked discipline in class'. In addition, that the teacher knows the students' weaknesses and gets involved to improve them is greatly valued on the part of the students. The teacher knows the students personally and this makes them feel free to ask questions and doubts. Students emphasise the teacher managed to adapt to their needs and that this 'created an agreeable and efficient work atmosphere in class'.

The last question was Do you think your language skills have improved over the year? In what ways? The vast majority of the students in the three groups reported having improved their language skills, namely $80.55 \%$ (29 out of 36) in Group A, 75.86\% (22 out of 29 ) in Group B and $97.67 \%$ (42 out of 43 ) in Group C. Yet some students claim that they learned on their own or thanks to private teachers. More specifically, students reported having improved their writing skills and their grammar but not their speaking abilities, once again pointing the need for reduced groups to favour the practice of speaking skills.

\section{Discussion}

The purpose of the study was to analyse the EFL students' perceptions of verbal and nonverbal teacher immediacy in three different groups taught by three lecturers with a very different profile and to determine if these perceptions correlate with the students' perceived FL anxiety. As expected, the three different teacher profiles yielded three significantly different degrees of perceived verbal and nonverbal immediacy on the part of the observers, which allowed us to continue with the study of the students' perceptions.

Within each of the groups and irrespectively of which teacher is perceived as more immediate than others, nonverbal immediacy was found to be significantly higher than verbal immediacy. As was mentioned above, nonverbal immediacy has been given more importance in classroom research, as it may exist independently of verbal messages. In an EFL classroom where neither the teachers nor the students are native speakers of English, nonverbal messages of immediacy are necessarily easier to be sent and to be interpreted as such. The three lecturers managed to handle nonverbal immediacy in a much more noticeable way than verbal immediacy. Immediacy is linked to affect and emotion and it is always easier for teachers to express this in their native language even though they are proficient speakers of English. As for the students and although this was an Advanced EFL course, verbal messages of immediacy in a foreign language might not be easily interpreted as such.

Comparisons of immediacy perceptions between the groups revealed that, in line with the observers, the three groups differed significantly from one another in terms of perceptions of both verbal and nonverbal immediacy. Teacher A was perceived as the least immediate, both verbally and nonverbally, and in fact, when asked by the researcher, she reported not feeling at ease with the course and the students. The fact that she was an inexperienced teacher, not used to university students and not familiar with the course and all its particularities might have influenced her attitude, which is clearly reflected in her students' questionnaires. Teacher B's immediacy was significantly higher than Teacher A's but significantly lower than Teacher C's. She was an experienced university lecturer but it was the first time she taught the course and she was new in the Department, all of which might have increased her lack of self-confidence and might have influenced her attitude in class. She reported not feeling completely comfortable in class although her willingness and disposition were on the whole 
very positive. Teacher $\mathrm{C}$ was perceived as the most immediate, which might have been caused by the fact that she knew the context, the course and the type of students she had to face.

As for FL anxiety, Group A reported feeling significantly more anxious than Groups B and $\mathrm{C}$, which did not significantly differ from each other. Hence, the group which reported the lowest degree of lecturer immediacy also reported the highest degree of FL anxiety. FL anxiety mean scores in the other two groups were not particularly low either but still significantly lower than in Group A. No statistical relationship was found between perceptions of verbal and nonverbal immediacy and perceptions of FL anxiety in any of the groups, which suggests that FL anxiety in this context might be derived from other factors. Cultural factors might come into play here, as Spanish students have high expectations of immediacy and they perceive it as something normal. Immediacy might not be correlated with lack of anxiety because it is what is expected and hence anxiety appears independently of whether the lecturer is immediate or not (Gregersen, 2006). In any case, that no correlation was found between teacher immediacy and student FL anxiety does not mean that an immediate behaviour on the part of the teacher does not create a classroom atmosphere that encourages positive reinforcement and learning. As mentioned at the beginning of the article, the EFL course at hand creates anxiety in itself. Students usually have a lower level of English than required, passing the course essentially depends on passing a final written and oral exam, groups are generally large and the level of frustration is remarkably high. Improvement throughout the course occurs mainly thanks to extra private lessons or additional exposure that students receive. Attending the course does not suffice, since levels of English are too varied and the teacher-student ratio is too high. Not passing the course means having to pay an extra tuition fee the following year and a delay in the completion of their studies. Although no direct relationship between immediacy and lack of anxiety was found, the students' answers to the open questions indicated that lecturer immediacy helped increase students' motivation and willingness to learn and contributed to creating a relaxed environment in the classroom.

The different degrees of immediacy in each of the groups and the anxiety that this brings to students were clearly reflected in how the students described their perceptions on affective and cognitive learning. Interestingly, the majority of students reported an increase in their cognitive learning, no matter what their perceptions on immediacy were. In relation to affective learning, students made it clear that approachable attitudes favoured their attitude to language learning and their motivation and self-confidence creating a relaxed and encouraging atmosphere, which is in line with previous research (Gorham, 1988: Cristophel, 1990: Plax et al., 1986; Richmond et al. 1987; McCroskey et al., 1987; Rodríguez et al., 1996; Richmond, 2002). Students' responses suggested that lack of immediacy might be related to lack of self-confidence and/or experience on the part of the lecturer and lack of knowledge of the course. Students generally reported the need for reduced groups to favour personalised learning, which helps create the right conditions for improvement. Lecturers should ideally be both agreeable and strict at the same time and provide positive reinforcement in class.

\section{Conclusion}

This study has explored the importance of verbal and nonverbal teacher immediacy behaviours in an EFL university course. Three lecturers with three different profiles were rated by their students in terms of their approachability and results were explored in rela- 
tion to the students' perceived levels of FL anxiety. Although significant differences were found between the groups with respect to immediacy and anxiety, the two key issues in the study were not statistically correlated, indicating that FL anxiety, albeit present in the groups, was also derived from other factors, including the nature of the course itself. The present study was limited in several ways. The fact that a convenience sample was used makes results not transferable to other learning contexts. At the same time, using a course which is anxiety-provoking in itself has surely affected our results. However, and especially through the students qualitative comments on their perceptions, results seem to suggest that immediate behaviours do help motivate students and create a classroom atmosphere that is favourable to effort and improvement. Students who perceived teacher immediate behaviours in the groups studied felt more inclined to participate and more self-confident in their language skills. Immediacy appears to favour affect in any classroom situation but further research is necessary, particularly in foreign language learning classrooms, where emotion plays a central role.

\section{REFERENCES}

Andersen, J. F. (1979). "Teacher immediacy as a predictor of teaching effectiveness", in D. Nimmo (ed.), Communication yearbook 3. New Brunswick, NJ: Transaction Books, 543-559.

Chesebro, J. and McCroskey, J. C. (1998). "The relationship of teacher clarity and teacher immediacy with students' experiences of state receiver apprehension", in Communication Quarterly, 46: 446-456.

Christophel, D. M. (1990). "The relationships among teacher immediacy behaviours, student motivation, and learning", in Communication Education, 37: 323-340.

Dewaele, J-M. (2007). "Predicting language learners' grades in the L1, L2, L3 and L4: The effect of some psychological and sociocognitive variables", in International Journal of Multilingualism, 4, 3: 169-197.

Edwards, A., \& Edwards, C. (2001). "The impact of instructor verbal and nonverbal immediacy on student perceptions of attractiveness and homophily", in Journal of Excellence in College Teaching, 12, 2: 5-17.

Gardner, R. C. (1985). Social Psychology and Second Language Learning: The Role of Attitudes and Motivation. London: Edward Arnold.

Gardner, R. and MacIntyre, P. D. (1993). "On the measurement of affective variables in second language learning", in Language Learning, 43: 157-194.

Gorham, J. (1988). "The relationship between verbal teacher immediacy behaviors and student learning", in Communication Education, 37: 40-53.

Gregersen, T. (2003). "To err is human: A reminder to teachers of language-anxious students", in Foreign Language Annals, 36: 25-32.

Gregersen, T. (2005). "Nonverbal cues: Clues to the detection of foreign language anxiety", in Foreign Language Annals, 38: 388-400.

Gregersen, T. (2006). "A cross-cultural comparison of nonverbal teacher immediacy and foreign language anxiety in Chilean and Russian English language classrooms", in Revista Signos, 39, 62: 407-426.

Horwitz, E. K. (2001). "Language anxiety and Achievement", in Annual Review of Applied Linguistics, 21: 112-126. 
Horwitz, E. K., Horwitz, M. B., and Cope, J. (1986). "Foreign language classroom anxiety", in Modern Language Journal, 70, 2: 125-132.

Hsu, L. (2010). “The Impact of Perceived Teachers' Nonverbal Immediacy on Students' Motivation for Learning English", in Asian EFL Journal, 12, 4: 1-17.

Kelley, D. H., and Gorham, J. (1988). "Effects of immediacy on recall of information", in Communication Education, 37: 198-207.

McCroskey, J. C, and Richmond, V. P. (1992). "Increasing teacher influence through immediacy", in V. P. Richmond \& J. C. McCroskey (eds.), Power in the classroom: Communication, control, and concern. Hillsdale, NJ: Lawrence Eribaum, 101-120.

McCroskey, J. C., Richmond, V. P. and McCroskey, L. L. (2005). An Introduction to Communication in the Classroom: The Role of Communication in Teaching and Training. Boston: Pearson.

MacIntyre, P. D. and Gardner, R. C. (1991). "Methods and results in the study of anxiety in language learning: A review of the literature", in Language Learning, 41:85-117.

MacIntyre, P. D. and Gregersen, T. (2012a). "Emotions that facilitate language learning: the positive broadening power of imagination", in Studies in Second Language Learning and Teaching, 2, 2: 193-213.

MacIntyre, P. D. and Gregersen, T. (2012b). "Affect: The role of language anxiety and other emotions in language learning", in S. Mercer, S. Ryan, and M. Williams (eds.), Language learning psychology: Research, theory and pedagogy. Basingstoke: Palgrave, 103-118.

Mehrabian, A. (1969). "Some referents and measures of nonverbal behavior", in Behavioural Research Methods and Instrumentation, 1: 213-217.

Messman, S. J., and Jones-Corley, J. (2001). "Effects of communication environment, immediacy, and communication apprehension on cognitive and affective learning", in Communication Monographs, 68: 184-200.

Myers, S. A. and Bryant, L. E. (2002). "Perceived understanding, interaction involvement, and college student outcomes", in Communication Research Reports, 19: 146-155.

Plax, T. G., Kearney, P., McCroskey, J. C., and Richmond, V. P. (1986). "Power in the classroom VI: Verbal control strategies, nonverbal immediacy, and affective learning", in Сommunication Education, 35: 43-55.

Pogue, L. L. and AhYun, K. (2006). "The Effect of Teacher Nonverbal Immediacy and Credibility on Student Motivation and Affective Learning", in Communication Education, 55, 3: 331-344.

Richmond, V. P. (1990). "Communication in the classroom: Power and motivation", in Communication Education, 39 : 181-195.

Richmond, V. P. (2002). "Teaching nonverbal immediacy", in J. L. Chesebro (ed.), Communication for teachers. Boston, MA: Allyn and Bacon, 65-82.

Richmond, V. P. and McCroskey, J. C. (1998). Communication apprehension, avoidance and effectiveness. Boston, MA: Allyn and Bacon.

Richmond, V. P. and McCroskey, J. C. (2000).Nonverbal behavior in interpersonal relationships. Boston, MA: Allyn and Bacon.

Richmond, V. P., Gorham, J. S., and McCroskey, J. C. (1987). "The relationship between selected immediacy behaviors and cognitive learning", in M. L. McLaughlin (ed.), Communication yearbook 10. Newbury Park, CA: Sage, 574-590.

Richmond, V. P. , McCroskey, I. C., Kearney, P. and Plax, T. G. (1987). "Power in the classroom VII: Linking behavior alteration techniques to cognitive learning", in Communication Education, 36: 1-12.

Rodriguez, J. I., Plax, T. G., and Kearney, P. (1996). "Clarifying the relationship between teacher nonverbal immediacy and student cognitive learning: Affective learning as the central causal mediator", in Communication Education , 45: 293-305. 
Saito, Y., Garza, T. J. and Horwitz, E. K. (1999). "Foreign language reading anxiety", in The Modern Language Journal, 83: 202-218.

Sellers, V. D. (2000). "Anxiety and reading comprehension in Spanish as a foreign language", in Foreign Language Annals, 33: 512-520.

Witt, P. L., and Wheeless, L. R. (2001). "An experimental study of teachers' verbal and nonverbal immediacy and students' affective and cognitive learning", in Communication Education, 50: $327-342$.

Witt, P. L., Wheeless, L. R., and Allen, M. (2004). "A meta-analytical review of the relationship between teacher immediacy and student learning", in Communication Monographs, 71: 184-207. 


\section{APPENDIX A}

Instructions: Please circle the answer that best describes your EFL teacher:

$1=$ Never $\quad 2=$ Rarely $3=$ Sometimes $\quad 4=$ Often $\quad 5=$ Very often

Verbal items:

1. Uses personal examples or talks about experiences she/he has had outside of class.

2. Asks questions or encourages students to talk.

3. Gets into discussions based on something a student brings up even when this doesn't seem to be part of his/her lecture plan.

4. Uses humor in class.

5. Addresses students by name.

6. Addresses me by name.

7. Gets into conversations with individual students before or after class

8. Has initiated conversations with me before, after or outside of class.

9. Refers to class as "my" class or what "I " am doing.

10. Refers to class as "our" class or what "we" are doing.

11. Provides feedback on my individual work through comments on papers, oral discussions, etc.

12. Calls on students to answer questions even if they have not indicated that they want to talk.

13. Asks how students feel about an assignment, due date or discussion topic.

14. Invites students to telephone or meet with him/her outside of class if they have questions or want to discuss something.

15. Asks questions that have specific, correct answers.

16. Asks questions that solicit viewpoints or opinions.

17. Praises students' work, actions or comments.

18. Criticizes or points out faults in students' work, actions or comments.

19. Will have discussions about things unrelated to class with individual students or with the class as a whole.

20. Is addressed by his/her first name by the students.

Nonverbal items:

21. Sits behind desk while teaching.

22. Gestures while talking to class.

23. Uses monotone/dull voice when talking to class.

24. Looks at class while talking.

25. Smiles at the class as a whole, not just individual students.

26. Has a very tense body position while talking to the class.

27. Moves around the classroom while teaching.

28. Sits on a desk or in a chair while teaching.

29. Looks at the board or notes while talking to the class.

30. Stands behind podium or desk while teaching.

31. Has a very relaxed body position while talking to the class.

32. Smiles at individual students in the class.

33. Uses a variety of vocal expressions while talking to the class. 


\section{APPENDIX B \\ FOREIGN LANGUAGE CLASSROOM ANXIETY SCALE}

Instructions: Please circle the answer that best describes your thoughts/feelings.

$$
\begin{array}{ll}
\mathrm{SA}=\text { Strongly Agree } & \mathrm{A}=\text { Agree } \quad \mathrm{N}=\text { Neither Agree nor Disagree } \\
\mathrm{D}=\text { Disagree } & \mathrm{SD}=\text { Strongly Disagree }
\end{array}
$$

1. I never feel quite sure of myself when I am speaking in my foreign language class.

2. I don't worry about making mistakes in language class.

3. I tremble when I know that I'm going to be called on in language class.

4. It frightens me when I don't understand what the teacher is saying in the foreign language.

5. It wouldn't bother me at all to take more foreign language classes.

6. During language class, I find myself thinking about things that have nothing to do with the course

7. I keep thinking that the other students are better at languages than me.

8. I am usually at ease during tests in my language class.

9. I start to panic when I have to speak without preparation in language class.

10. I worry about the consequences of failing my foreign language class.

11. I don't understand why some people get so upset over foreign language classes.

12. In language class, I can get so nervous I forget things I know.

13. It embarrasses me to volunteer answers in my language class.

14. I would not be nervous speaking the foreign language with native speakers.

15. I get upset when I don't understand what the teacher is correcting.

16. Even if I am well prepared for language class, I feel anxious about it.

17. I often feel like not going to my language class.

18. I feel confident when I speak in foreign language class.

19. I am afraid that my language teacher is ready to correct every mistake I make.

20. I can feel my heart pounding when I'm going to be called on in language class.

21. The more I study for a language test, the more confused I get.

22. I don't feel pressure to prepare very well for language class.

23. I always feel that the other students speak the foreign language better than I do.

24. I feel very self-conscious about speaking the foreign language in front of other students.

25. Language class moves so quickly I worry about getting left behind.

26. I feel more tense and nervous in my language class than in my other classes.

27. I get nervous and confused when I am speaking in my language class.

28. When I'm on my way to language class, I feel very sure and relaxed.

29. I get nervous when I don't understand every word the language teacher says.

30. I feel overwhelmed by the number of rules you have to learn to speak a foreign language.

31. I am afraid that the other students will laugh at me when I speak the foreign language.

32. I would probably feel comfortable around native speakers of the foreign language

33. I get nervous when the language teacher asks questions which I haven't prepared in advance. 